\title{
Comparative Study of Performances of a Single-Cylinder Diesel Enginefueled with Pure Diesel and Blends of Biodiesels/Pure Diesel
}

\author{
H. Mbanza Dinganga1, Y. Tuakashikila Muamba ${ }^{2}$, C. Tumuinimo Mambote ${ }^{1}$, \\ A. Malumba Mukaya², J. Lami Nzunzu' ${ }^{3}$, V. Sumuna Temo1,4, \\ H. Mbuyi Katshiatshia ${ }^{1,4^{*}}$
}

${ }^{1}$ Center for Research in Energy and Applied Informatics (CREI), Faculty of Polytechnics, Université Kongo, Mbanza-Ngungu, DRC

${ }^{2}$ Laboratory of Analytical Chemistry, Faculty of Sciences, Université de Kinshasa, Kinshasa, DRC

${ }^{3}$ Laboratory of Bioorganic Research (Larebiorg), Faculty of Pharmaceutical Sciences, Université de Kinshasa, Kinshasa, DRC

${ }^{4}$ Center for Research in Renewable Energies (CRRE), Faculty of Polytechnics, Université de Kinshasa, Kinshasa, DRC

Email: ^haddy.mbuyi@unikin.ac.cd

How to cite this paper: Mbanza, H.D., Tuakashikila, Y.M., Tumuinimo, C.M., Malumba, A.M., Lami, J.N., Sumuna, V.T., and Katshiatshia, H.M. (2021) Comparative Study of Performances of a Single-Cylinder Diesel Enginefueled with Pure Diesel and Blends of Biodiesels/Pure Diesel. Energy and Power Engineering, 13, 111-125. https://doi.org/10.4236/epe.2021.133008

Received: February 3, 2021

Accepted: March 28, 2021

Published: March 31, 2021

Copyright $\odot 2021$ by author(s) and Scientific Research Publishing Inc. This work is licensed under the Creative Commons Attribution International License (CC BY 4.0).

http://creativecommons.org/licenses/by/4.0/ (c) (i) Open Access

\begin{abstract}
In this study, the principal objective is to compare the performances of an air-cooled one cylinder, four-stroke direct injection diesel engine using the blends ( $5 \%$ by volume B5, 10\% by volume B10) of diesel and biodiesels derived respectively from palm oil, castor oil and raphia sese De Wild oil with pure diesel. All the biodiesels used in this work come from the plant species of the democratic republic of Congo as listed above. The engine performances (power, torque and brake specific consumption) at different engine speeds were determined at both full and partial loads. According to experimental results, the increments in the power output and torque when the mixtures of diesel and biodiesels were used and were observed. On the other side, the specific fuel consumption of the mixtures is higher than that of pure diesel although the calculated lower heating values are almost within the same range for the all studied fuels. Finally, in partial load 1/1, pure diesel blended with biodiesels B5 derived from castor oil presented high specific brake consumption values compared to the other fuels while $\mathrm{B} 10$ from the same oil presents low brake specific consumption values for power greater than $3.2 \mathrm{~kW}$.
\end{abstract}

\section{Keywords}

Diesel Monocylinder Engine, Performances, Biodiesels-Gasoil Blends 


\section{Introduction}

The energy accessibility is the first challenge of this century. More forms of resources are used to produce energy. However, the environment pollution due to the usage of fossil fuels is the main problem that must be solved for these decades. Many scientists propose a diversification of the energy production by using raw vegetable materials that are renewable and sustainable [1] [2]. Among them, biodiesel can be produced and used in the compression ignition engine in replacement of traditional diesel. We note that these fuels have similar physicochemical properties with the fossil fuels [3] [4].

Compared to the spark engine, the diesel engine produces more pollutants during the combustion of its fuel even though its high compression ratio leads to a good thermal yield [5]. Carbon dioxide $\left(\mathrm{CO}_{2}\right)$, carbon monoxide (CO), Nitrogen oxides $\left(\mathrm{NO}_{\mathrm{x}}\right)$, Hydrocarbons $(\mathrm{HC})$ and fine material particles $(\mathrm{PM})$ are the important pollutants resulting from diesel engines [6] [7] [8] [9].

To propose an alternative solution, the transesterification reaction can be used to produce biodiesel from vegetable or animal oils. Many authors studied the performances of the internal combustion engine fueled with biodiesel and described its combustion characteristics [10] [11]. Biodiesel presents more advantages than the fossil diesel. It is a renewable energy resource, less toxic, biodegradable and products less pollutants during its combustion [12]. Luka et al. noticed the introduction of biodiesel, even in small amounts, leads to the reduction of $\mathrm{CO}$ and $\mathrm{NO}_{\mathrm{x}}$ at different speeds of a diesel engine fueled with neat biodiesel made from rapeseed oil and their blends (B25, B50 and B75). The presence of oxygen in the biodiesel chemical structure was found as the main contribution of this reduction [13]. Indeed, the biodiesel chemical structure has an effect on the exhaust emissions. In addition, the combination of the chain length (number of carbon) and the unsaturation degree of fatty acid methyl esters has an important role in the $\mathrm{NO}_{\mathrm{x}}$ emissions [14]. Even, the emissions of $\mathrm{CO}$, total $\mathrm{HC}$, volatile organic fraction and soot increased with the chain length, as related by the same author. While using pentanol blends to diesel and biodiesel, at different ratios, in a single-cylinder direct injection diesel engine; the soot formation increased with the pentanol addition. Therefore, the $\mathrm{NO}_{\mathrm{x}}$ emissions were reduced. The same behavior was detected for the exhaust containing oxygen atom such as $\mathrm{CO}$ and $\mathrm{CO}_{2}[15]$.

Furthermore, biodiesel presents disadvantages, for having a weak energy capacity. It is noticed that this fuel is less favorable to cold flow due to its high viscosity that contributes to the volatility properties during its combustion [5].

To improve these disadvantages, several researches were carried out with various types of biodiesels [16] [17]. The main solution proposed by many authors is a blend of this product with the traditional fossil fuels in many proportions. So, the abbreviations of B5, B10, ..., B100 are used to show the amount of biodiesel in the mixtures [7].

Compared to biodiesel, the combustion characteristic of ethanol-biodiesel 
blends (BE5) in a 4-cylinder direct-injection diesel engine presented a higher brake thermal efficiency (BTE) and leaded to the reduction of $\mathrm{NO}_{\mathrm{x}}$ and particulate emissions [7]. The author concluded that by increasing the proportion of ethanol in the blends, the $\mathrm{HC}$ and $\mathrm{CO}$ emissions could increase.

The specific fuel consumption and the brake thermal efficiency of a low heat rejection diesel engine (Mercedes-Benz/OM364A) were improved by using biodiesel produced from sunflower oil and the determination of the exhaust gas temperature were performed and showed that this parameter was increased before the turbine inlet for the studied fuels [18]. In the same way, the usage of biodiesel in in-line 6 cylinders, intercooled, turbocharged diesel engine at high altitude improved the increase of the brake specific fuel consumption (BSFC) and the volumetric brake specific fuel consumption. According to the previous parameters, the brake thermal efficiency was slightly higher while using diesel than biodiesel [19].

To predict the brake power, torque, specific fuel consumption and exhaust emissions of a 2 cylinders-RD270 Ruggerini diesel engine, running with biodiesel obtained from waste vegetable cooking oil of a restaurant, the neutral network design was used. The results showed that the brake specific fuel consumption of the fuel blends (B10, B20, B30, B40 and B50) compared to diesel (B0) is very similar. However, the increasing fuel blend percentage leaded to a mild increase of the brake specific fuel consumption. The variations of the power and the engine torque per the engine speed were very similar for the all studied fuels [20].

The emissions characteristics of a diesel engine operating on biodiesel and biodiesel blended with ethanol and methanol showed that the increasing of the alcohol amount in the fuel decreased the emissions of $\mathrm{NO}_{\mathrm{x}}$ and $\mathrm{PM}$. However, $\mathrm{HC}$ and $\mathrm{CO}$ emissions could increase and the brake thermal efficiency could slightly reduce by the use of more than $5 \%$ of alcohol in the blends [7]. In the same way, a delayed start of combustion and lower combustion duration are observed for biodiesel-methanol blend compared to neat biodiesel fuel in four cylinder in-line turbocharged direct injection diesel engine [21]. The authors showed that the addition of $10 \%$ of methanol improved the increasing of the thermal efficiency by $4.2 \%$.

To determine the proportion between biodiesel and diesel for compression ignition engines, the main injection and the atomization properties related to the quality of ignition were measured. The authors noticed that the blends from B2 to B30 present satisfactory properties for their usage in diesel engines. This study was based on the soybean ethylic biodiesel [22].

The effect of biodiesel addition on the diesel engine characteristics showed a slight deviation of the engine torque, power, brake specific consumption, exhaust gas temperature and $\mathrm{CO}-\mathrm{CO}_{2}$ emissions in function of the engine speeds. The biodiesel used was produced from Hazelnut soapstock and waste sunflower oil mixed in equal volume and tested on a 4-cyminders indirect injection diesel 
engine [23].

It is noticed that the preheating vegetable oils have a good effect on the oils physicochemical properties such as their density and their viscosity and then, on the combustion. This seems to present a benefit on the utilization of vegetable oils as fuels in internal combustion engines (for example in a diesel engine) [24].

This study aims to investigate the performances of a single-cylinder diesel engine using blends of diesel with biodiesels derived from palm oil, castor oil and raphia sese De Wild oil respectively with pure diesel. The measurements of the engine performances for different engine speeds at full load, on the one hand, and at constant speed for the partial loads on the other hand are improved respectively.

\section{Materials and Methods}

\subsection{Materials}

The engine used in this study is a mono-cylinder and direct injection diesel engine cooled by air. The mechanical characteristics of this engine are presented in Table 1.

The experimental setup is composed of a modular test bench for single-cylinder engines CT 159 containing a universal unit of braking and drive HM 365 connected to the engine test CT 151. The all experimental setup is presented in Figure 1.

The test setup was connected to the computer via a command unit. The software allowed the acquisition of all the experimental data during the experiments. It is noticed that the unit HM 365 is used for starting the diesel engine CT 159. This compression ignition engine is connected to the brake composed by the unit HM 365, used such as a screw-locking device.

The principal parties of the experimental are presented in Figure 2, as below.

During the tests, a basic module CT 159 is used to measure the fuel consumption and the requirement in air for combustion. The control panel included digital display panels allowed to indicate the air consumption and the ambient, fuel and exhaust temperatures.

Table 1. Mechanical characteristics of diesel engine [25].

\begin{tabular}{cc}
\hline Engine type & Hatz 1 B20-6 \\
\hline Number of cylinder & 1 \\
Weight & Approximately $30 \mathrm{~kg}$ \\
Bore & $69 \mathrm{~mm}$ \\
Stroke & $62 \mathrm{~mm}$ \\
Displacement & $232 \mathrm{~mm}^{3}$ \\
Power & $1.5 \mathrm{Kw}$ \\
Compression ratio & $21: 1$ \\
\hline
\end{tabular}




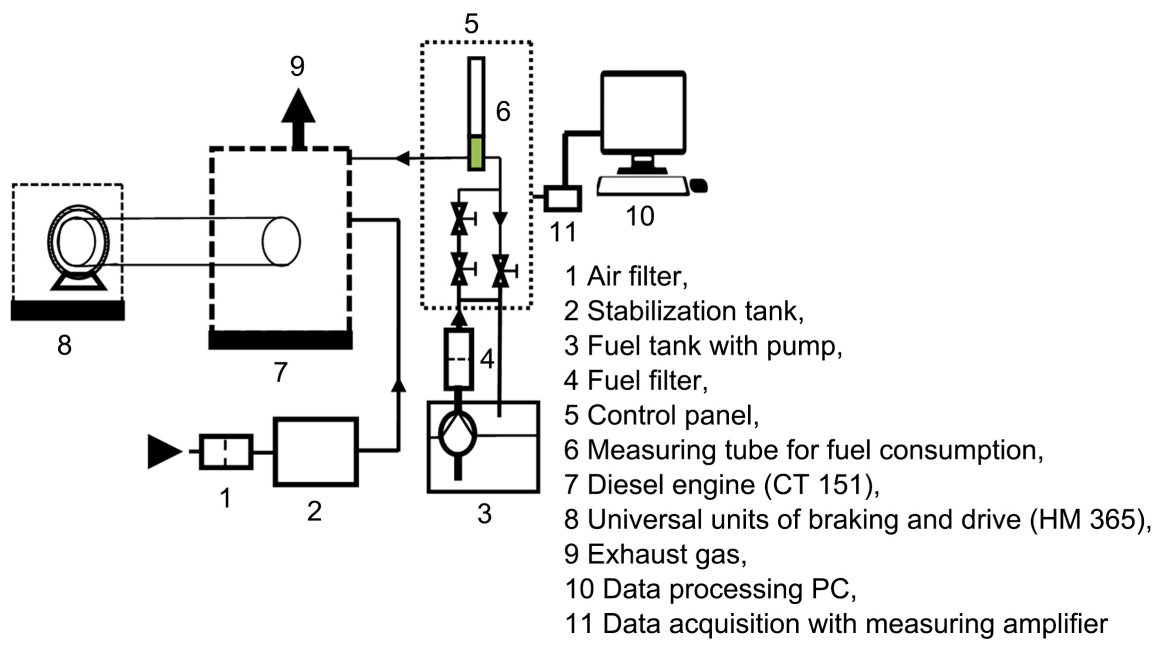

Figure 1. Experimental setup.

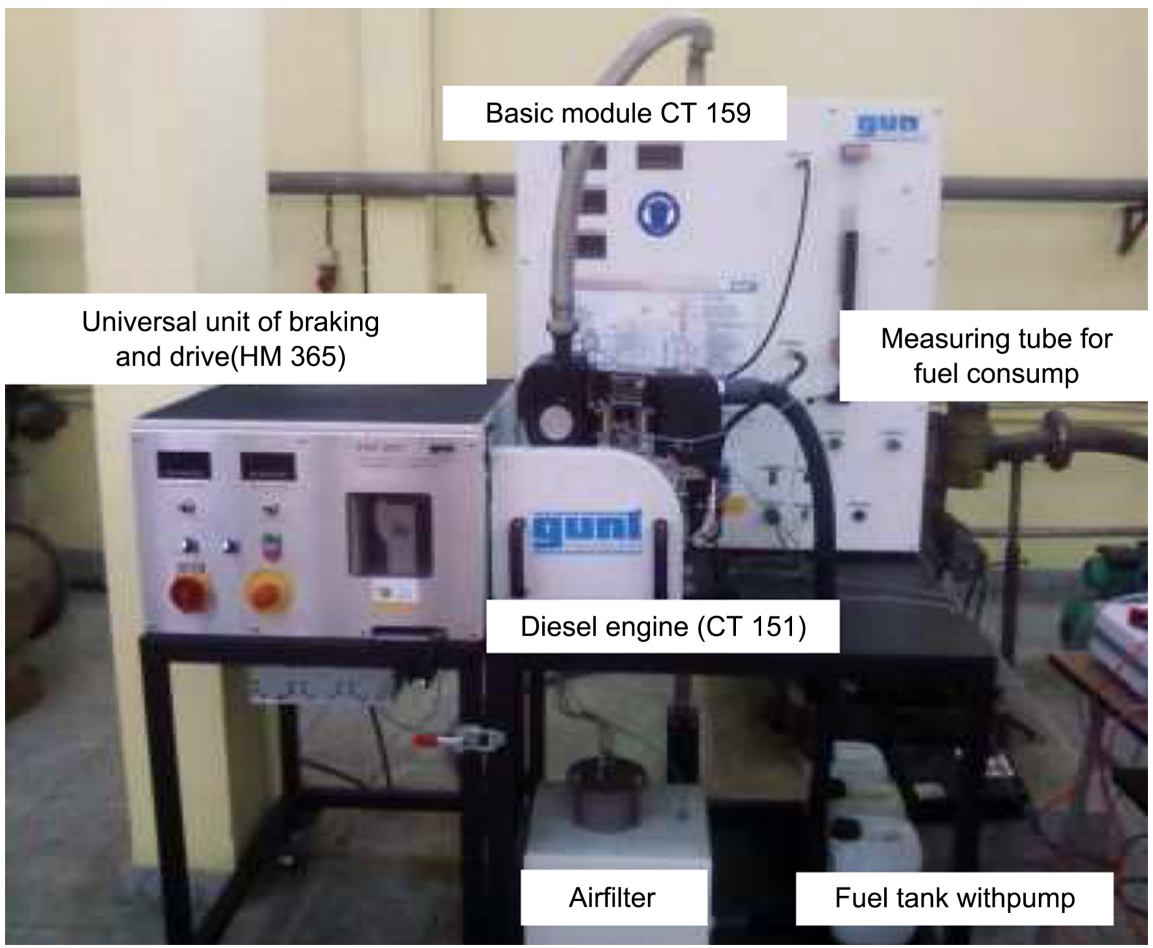

Figure 2. Principal parts of the experimental setup.

The connection between the diesel engine and the brake is assumed by a V-belt standard SPA 1250.

The fuels used in this work, are obtaining by blending the fossil diesel with different biodiesels produced from palm oil, castor oil and raphia sese De Wild oil [3]. The different fuels used in this work were obtained by a transesterification reaction as described in our previous paper [3]. Two types of fuels are used, $\mathrm{B} 5$ and B10 for each produced biodiesel.

Table 2 illustrates the physicochemical properties of the fuels used in this study. 
Table 2. Properties of diesel and blend diesel/biodiesel fuels [3].

\begin{tabular}{|c|c|c|c|c|c|c|c|c|c|}
\hline Properties & Units & Method & Diesel & B5C & B5P & B5R & B10C & $\mathrm{B} 10 \mathrm{P}$ & B10R \\
\hline Density at $15^{\circ} \mathrm{C}$ & $\mathrm{kg} / \mathrm{L}$ & ASTM D4052 & 0.8495 & 0.816 & 0.816 & 0.8533 & 0.820 & 0.819 & 0.8558 \\
\hline Kinematic viscosity at $40^{\circ} \mathrm{C}$ & $\mathrm{mm}^{2} / \mathrm{s}$ & ASTM D445 & 3.9 & 3.7 & 3.2 & 4.0 & 4.5 & 4.1 & 4.2 \\
\hline Total sulfur content & $\%$ & ASTM D4294 & 0.043 & 0.121 & 0.042 & 0.062 & 0.153 & 0.079 & 0.05 \\
\hline Lower Heating Value & $\mathrm{MJ} / \mathrm{kg}$ & Boite-a-outils/calculer-pci & 45.30 & 45.28 & 45.31 & 45.30 & 45.27 & 45.29 & 45.30 \\
\hline Copper strip corrosion & - & ASTM D130 & 1a & 1a & la & 1a & la & 1a & la \\
\hline Flash point & ${ }^{\circ} \mathrm{C}$ & ASTM D93 & 70 & 72 & 75 & 74 & 68 & 69 & 67 \\
\hline Cloud point & ${ }^{\circ} \mathrm{C}$ & ASTM D97 & -15 & -16 & -17 & -18 & -11 & -11 & -9 \\
\hline Cetane number & - & ASTM D976 & 48.5 & 49 & 51 & 50 & 50.2 & 50.8 & 49.5 \\
\hline
\end{tabular}

The lower heating values presented in Table 2 were calculated by using the on-line software proposed by total. Two values are needed to do this calculation: the density at $15^{\circ} \mathrm{C}$ and the total sulfur content [26].

\subsection{Methods}

The method used in this study consisted on the measurements of each mechanical parameter (brake specific consumption, power and torque) at different speeds. Each test was repeated five times to improve the reliability of the experimental data. Two modes were used, the full load and the partial one for the characterization of the diesel engines in the range of speed between 1500 and $2800 \mathrm{rpm}$.

\section{Results and Discussion}

The results presented in the following figures are obtained from the average of the experimental data at each speed and for the full load and at constant speed for the partial load. First, the engine was fueled by the fossil diesel and then, B5 were used. To complete the experiments, B10 were used to fuel the engine in the same conditions.

\subsection{Full Load}

Full load is defined as the stress that an engine can overcome without a reduction in speed. In full load, the engine is connected to a test rig at an operating temperature and with fully activated injection pump using a braking device. In this case, the largest possible quantity of fuel is made available. The values determined over the entire speed range under different loads are the basis for the curve progression of torque, power output and specific fuel consumption.

Figure 3 illustrate the single-cylinder diesel engine performances fueled by the blend of different biodiesel (raphia, palm and castor) with the fossil fuel. For these experiments, $10 \%$ of biodiesel was mixed with $90 \%$ of fossil diesel by vo- 
lume. The obtained fuels are called B10.

Figure 3(a) shows that the castor oil biodiesel blends to diesel (B10) presents a higher power at all the range of the experimental engine speed; then the palm biodiesel (B10). However, at low speed, the palm diesel presents high power than the fossil diesel that shows the same characteristic at high speed compared to palm oil biodiesel. Finally, the raphia biodiesel presents the lowest power at high speed compared to the previous fuels. Indeed, the same behavior is observed, as illustrated in Figure 3(b), where the engine torque is function of the speed engines. It is noticed that the percentage of biodiesel in mineral diesel does not affect the engine power and torque in the range of B0 to B50 [20]. However, a slight decrease in engine power and torque was observed when blending the mineral diesel with rapeseed oil biodiesel (B25, B50 and B75) and this is due to the lower calorific value of biodiesel fuels [13]. It is related that the power and torque engines of a 4-cylinders diesel engine fueled with the biodiesel produced from sunflower oil are higher than that obtained from fossil diesel from 1200 to $2800 \mathrm{rpm}$ [18] [23]. The results presented in the two Figure 3(a) and Figure 3(b) agree with the latest results presenting in literature. Furthermore, the biodiesel chemical structures confer to the blended fuel different properties due to the degree of unsaturation of fatty acid methyl or ethyl esters [14]. Then, the percentage of biodiesel in the mineral diesel has a good effect on the engine power for all the range of speed, but there is a slight decrease or torque at high speed [23]. In this study, the determinations of the chemical composition of different fuels were not performed.

The brake specific fuel consumption (BSFC) of the blended fuels increases with the engine speed as related in literature [7] [18] [19] [20] [23] [27]. The results presented in Figure 3(c) are in a good agreement with the main results found in literature. However, the brake specific fuel consumption of a 4-cylinders turbocharged indirect diesel engine fueled with a blend of jatropha biodiesel with butanol and diethyl ether decreased as the engine speed was increased from 1000 to $1500 \mathrm{rpm}$. The authors attributed this phenomenon to the increased atomization ratio. They related that after $1500 \mathrm{rpm}$, the inverse phenomenon is observed and they attributed it to the decreased volumetric efficiency during high speeds [11]. All the studied fuels present high value of the brake specific fuel consumption according their low calorific value due to the presence of biodiesel except for the pure diesel as shown in Figure 3(c).

It is noticed that at high speed the castor and the palm biodiesel (B10) present the same value where the raphia biodiesel and the fossil diesel have a same value. However, the fuel consumption of pure diesel is lower compared to the others for all the experiment speed range.

Figure 4 illustrate the single-cylinder diesel engine performances fueled by the blend of different biodiesel (raphia, palm and castor) with the fossil fuel. For these experiments, the fuels used were prepared by blending $5 \%$ of biodiesel and $95 \%$ of the fossil diesel. The obtained fuels are called B5. 


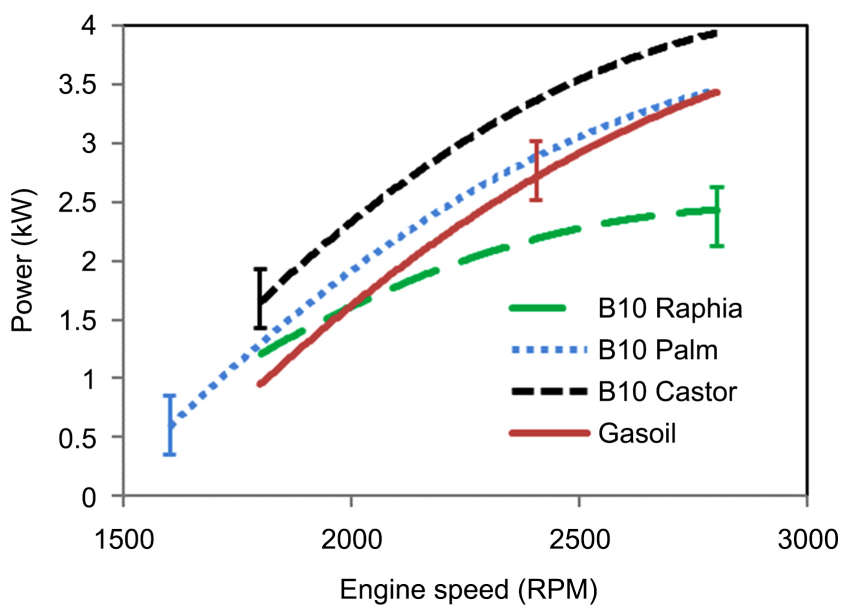

(a)

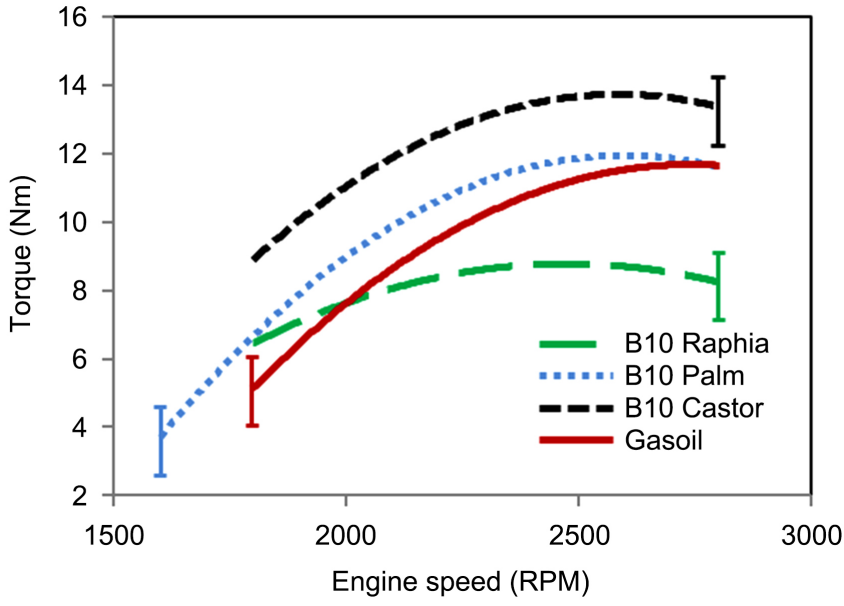

(b)

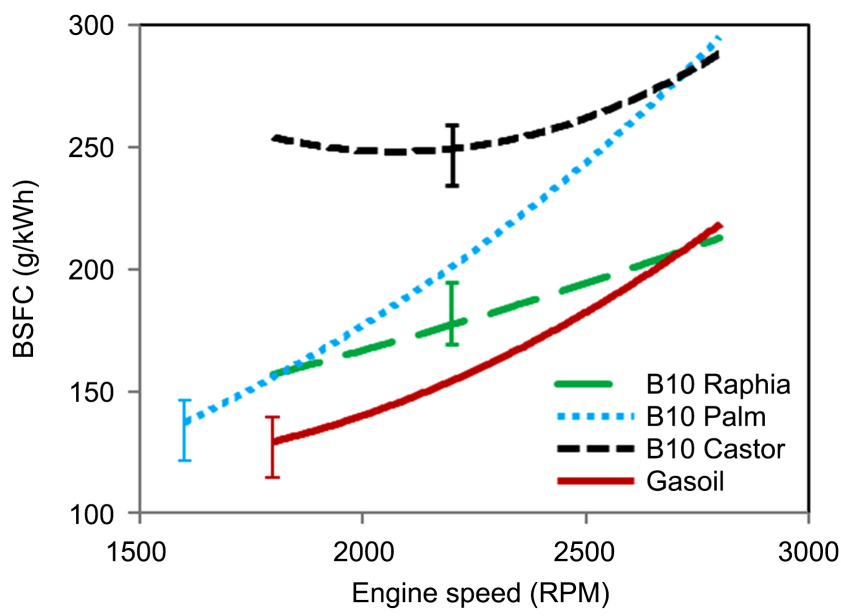

(c)

Figure 3. (a) Relationship between Engine power and engine speeds fueled with pure diesel compared to B10 of Raphia-biodiesel, Palm-biodiesel and Castor-biodiesel; (b) Relationship between Engine torque and engine speeds fueled with pure diesel compared to B10 of Raphia-biodiesel, Palm-biodiesel and Castor-biodiesel; (c) Relationship between The brake specific fuel consumption and engine speeds fueled with pure diesel compared to B10 of Raphia-biodiesel, Palm-biodiesel and Castor-biodiesel. 


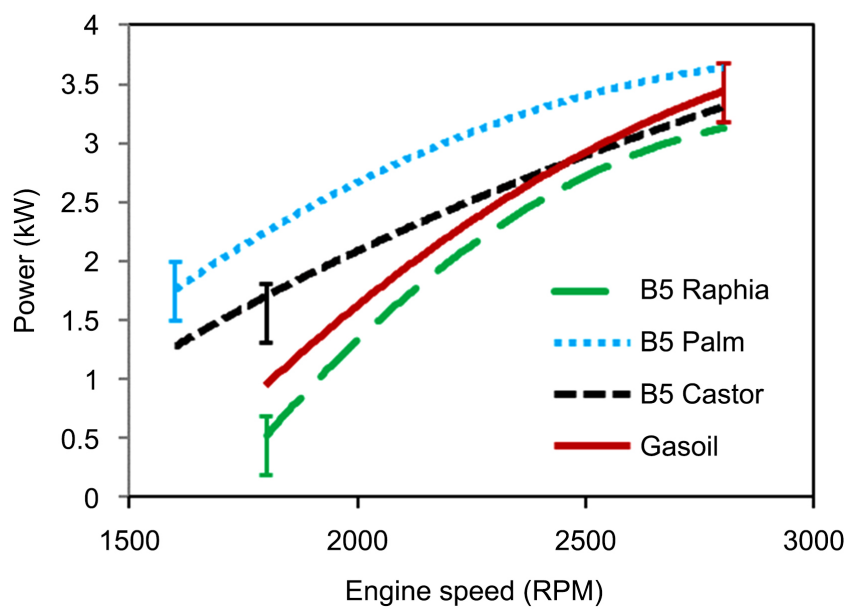

(a)

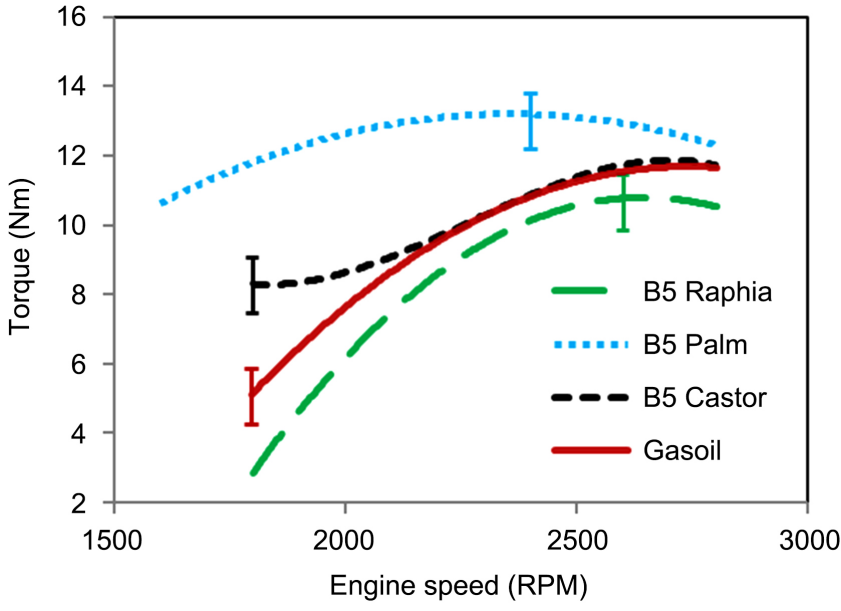

(b)

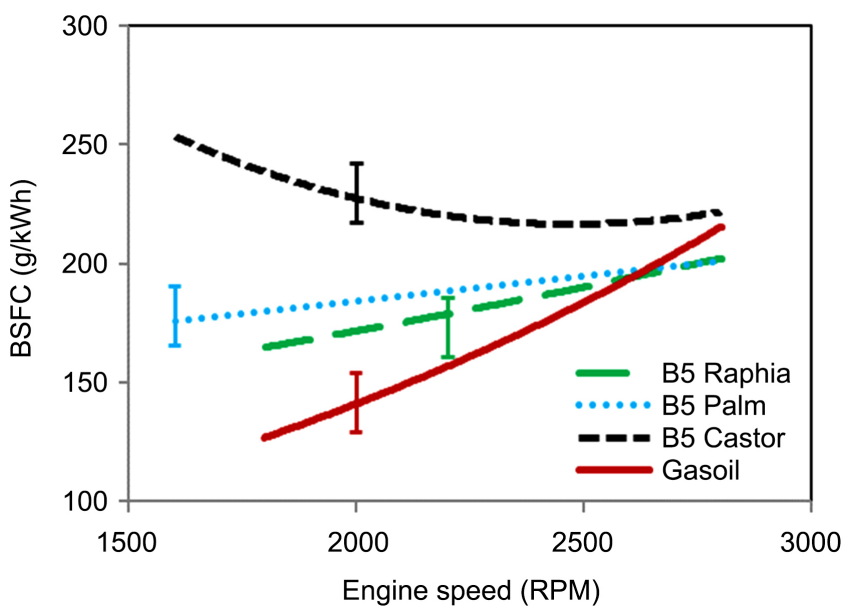

(c)

Figure 4. (a) Engine power corresponding on engine speeds fueled with pure diesel compared to B5 of Raphia-biodiesel, Palm-biodiesel and Castor-biodiesel; (b) Torque corresponding on engine speeds fueled with pure diesel compared to B5 of Raphia-biodiesel, Palm-biodiesel and Castor-biodiesel; (c) Specific fuel consumption corresponding on engine speeds fueled with pure diesel compared to B5 of Raphia-biodiesel, Palm-biodiesel and Castor-biodiesel. 
Therefore, there is a slight change in the engine performances while decreasing the biodiesel amount in the fuel.

The palm biodiesel B5 present more power than the other fuels for all the range speeds. It is followed by the castor biodiesel, then the pure diesel. The raphia sese De Wild biodiesel (B5) presents low power as depicted in Figure 4(a). However, there is a slight decrease of the released engine power according to the percentage of biodiesel in the studied fuels. Again, at high speed, all the fuels present the same value of engine power in taking into account the experimental error. These results agree well with those presented in literature [4] [13] [18] [28].

According to the results obtained and presented for B10, B5 are in good agreement by considering the engine torque at different engine speeds, as related in Figure 4(b). It is noticed that for B5 from palm biodiesel, the engine developed high torque values for the all studied range of engine speed. Therefore, from 1800 to $2000 \mathrm{rpm}$, for the B5 containing castor biodiesel, the engine torque is constant and increases after this range of speed. In their work on the fuel consumption and emissions from a diesel power generator fueled with castor oil and soybean biodiesel, Valente et al. didn't notice this behavior [28]. In our case, this phenomenon can be attributed to the engine mechanical characteristics. However, others investigations must be done to improve this behavior according to the literature results [28].

For the brake specific fuel consumption as illustrated in Figure 4(c), it decreases of the all blended fuels. This situation is improved by the decreasing of the biodiesel amount in the fuels that affect the calorific value. For B5, the lower heating value is higher compared to $\mathrm{B} 10$.

The comparison between the performances of the single diesel engine fueled with pure diesel and pure diesel blended with 5\% (B5) by volume of biodiesels derived from palm oil, castor oil and raphia sese oils (Figure 4). We observed that the curves have practically the same trends compared to that presented for B10 (Figure 3). But, the power output and the torque for the blends of pure diesel and raphia sese De Wild biodiesel are lower than for the three others fuels. We note that the three types of mixtures don't present the same chemical composition that affects their combustion, as related in literature [27]. However, the brake specific fuel consumption of pure diesel remained low compared to the blended fuels for the all full load studied cases.

\subsection{Partial Load}

For this type of measurements, the setup allowed to make the experiments at constant speed and under various loads of the engine. The availability of a sufficient amount of data makes it possible to establish performance characteristics for the engine when the pump admits the maximum quantity of fuel (full load) and then, the half quantity of the maximum (partial load 1/1). In this study, the partial load $1 / 1$ was used due to the experimental setup. 
The following Figure 5 present the results obtained, for the studied fuels, in these experiment conditions.

In partial load 1/1, the variations of specific fuel consumption versus the engine power are shown in Figure 5(a) and Figure 5(b). The specific fuel consumption of the pure diesel and pure diesel blended with biodiesels increases with the power for B5 palm, B5 raphia sese De Wild but decreases for B5 castor. The same observations were made for $\mathrm{B} 10$.

Imtenan et al. noticed that, the BSFC of their all studied fuels decreased as the engine speed was increased from $1000 \mathrm{rpm}$ to $1500 \mathrm{rpm}$. They attributed this behavior to the fact that the increasing of the atomization ratio can be responsible for such decrement. In addition, they noticed that the increment of BSFC after $1500 \mathrm{rpm}$ can be attributed to the decreased volumetric efficiency during the higher speeds [11]. In our case, as depicted in Figure 5(a) and Figure 5(b), we

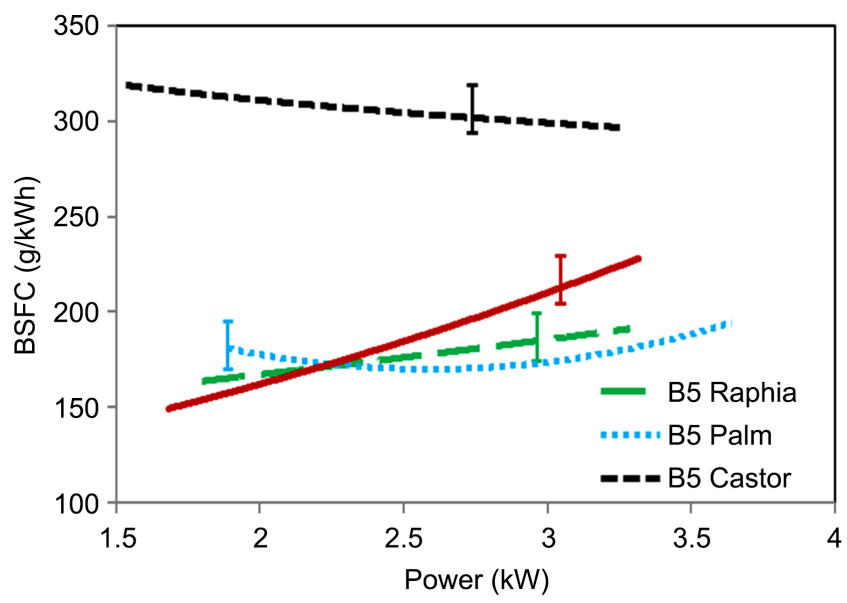

(a)

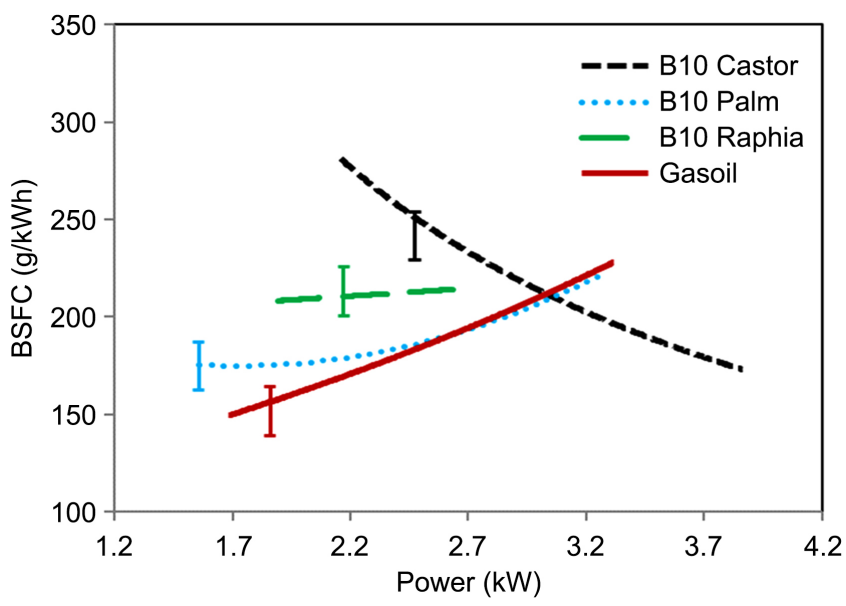

(b)

Figure 5. (a) The changes of specific fuel consumption according to engine power output in partial load 1/1 when the engine is fueled with B5 of the three biodiesels compared to the gasoil; (b) The changes of specific fuel consumption according to engine power output in partial load 1/1 when the engine is fueled with B10 of the three biodiesels compared to the gasoil. 
note that B5 and B10 from the castor oil biodiesel blended to the fossil fuels, the BSFC decreases with the increment of the engine power at partial load 1:1 at constant speed. For the other fuels, the BSFC increased with the increment of the engine power as shown in full load. For the first case (castor oil biodiesel/diesel), we can attribute this behavior to the blended fuel composition that can affect the atomization rate as well as the fuel-air mixing rate, compared to Imtenan et al. study [11]. Therefore, it seems to be important to determine the chemical composition of these fuels in order to show the relationship between the BSFC and the engine performance parameters at constant speed with a variation of the engine torque.

\section{Conclusions}

The main objective of this study was to determine the performances of a single cylinder diesel engine running on fossil diesel-biodiesel blends. The blends were obtained by mixing $90 \%$ of fossil diesel with $10 \%$ of biodiesel (B10) on the hand; and on the other hand by mixing $95 \%$ of the fossil diesel with $5 \%$ of biodiesel (B5). The three biodiesels were prepared by transesterification of raphia sese De Wild, castor and palm oils. Then, the various physicochemical parameters of different fuels were determined according to ASTM standards. All the prepared fuels present good properties according to the ASTM specifications compared to the reference diesel.

Two modes were used to make these experiments, the full load and the partial one. Based on the experimental results, we conclude that:

- In full load, the brake specific fuel consumption, the torque and the power output of these blends increase with the speed and are higher than that of pure diesel, except for the blend of pure diesel and raphia sese De Wild biodiesel.

- In partial load 1/1, the blends B5 and B10 between castor biodiesel and fossil diesel present a different appearance than the other fuels under the same working conditions. These fuels seem to be not adapted in this mode and other investigations must be done to improve the use of these fuels in the diesel engine.

The pure diesel blended with biodiesels derived from raphia sese De Wild has the performance near to pure diesel.

According to the obtained results, the studied fuels produced from Congolese plant species can be used, in blend form with the fossil diesel, as diesel engine fuels.

The authors recommend the further studies be carried out to determine the emissions of different fuels in order to determine their effect on the environment.

\section{Acknowledgements}

The authors sincerely thank Mrs. Mpaka Papy and Kaseya Héritier (Chemistry 
and Engine and Fuel Laboratory Technicians) for the contribution during the laboratory tests.

\section{Conflicts of Interest}

The authors declare no conflicts of interest regarding the publication of this paper.

\section{References}

[1] Poitrat, E., (1992) Technique de l'ingénieur, traité génie énergétique, BE8550. Biocarburants.

[2] Srivastava, A. and Prasad, R. (2000) Triglycerides-Based Diesel Fuels. Renewable and Sustainable Energy Reviews, 4, 111-33. https://doi.org/10.1016/S1364-0321(99)00013-1

[3] Tuakashikila Muamba, Y., Mbanza Dinganga, H., Tumuinimo Mambote, C., Malumba Mukaya, A., Lami Nzunzu, J., Sumuna Temo, V. and Mbuyi Katshiatshia, H. (2018) Physicochemical Characterization of Biodiesel Produced from Oil Extract from the Pulp of Raphia Sese de Wild Collected in Democratic Republic of Congo. American Scientific Research Journal for Engineering Technology and Science (ASRJETS), 44, 89-102.

[4] Valentino, G., Allocca, L., Iannuzzi, S. and Montanaro, A. (2011) Biodiesel/Mineral Diesel Fuel Mixtures: Spray Evolution, Engine Performance and Emissions Characterization. Energy, 36, 3924-3932. https://doi.org/10.1016/j.energy.2010.10.052

[5] Sun, J., Caton, J.A. and Jacobs, T.J. (2010) Oxides of Nitrogen Emissions from Biodiesel-Fuelled Diesel Engines. Progress in Energy and Combustion Science, 36, 677-695. https://doi.org/10.1016/j.pecs.2010.02.004

[6] Huang, J.C., Wang, Y.D., Qin, J.B. and Roskilly, A.P. (2010) Comparative Study of Performance and Emissions of a Diesel Engine Using Chinese Pistache and Jatropha Biodiesel. Fuel Processing Technology, 91, 1761-1767. https://doi.org/10.1016/j.fuproc.2010.07.017

[7] Zhu, L., Cheung, C.S., Zhang, W.G. and Huang, Z. (2010) Emissions Characteristics of a Diesel Engine Operating on Biodiesel and Biodiesel Blended with Ethanol and Methanol. Science of the Total Environment, 408, 914-921.

https://doi.org/10.1016/j.scitotenv.2009.10.078

[8] Moon, G. Lee, Y., Choi, K. and Jeong, D. (2010) Emission Characteristics of Diesel, Gas to Liquid, and Biodiesel-Blended Fuels in a Diesel Engine for Passenger Cars. Fuel, 89, 3840-3846. https://doi.org/10.1016/j.fuel.2010.07.009

[9] Zhu, L., Cheung, C.S., Zhang, W.G. and Huang, Z. (2011) Combustion, Performance and Emission Characteristics of a DI Diesel Engine Fueled with Ethanol-Biodiesel blends. Fuel, 90, 1743-1750. https://doi.org/10.1016/j.fuel.2011.01.024

[10] Lin, Y., Wu, Y.G. and Chang, C.T. (2007) Combustion Characteristics of Waste-Oil Produced Biodiesel/Diesel Fuel Blends. Fuel, 86, 1772-1780. https://doi.org/10.1016/j.fuel.2007.01.012

[11] Imtenan, S., Masjuki, H.H., Varman, M., Rizwanul Fattah, I.M., Sajjad, H. and Arbab, M.I. (2015) Effect of N-Butanol and Diethyl Ether as Oxygenated Additives on Combustion-Emission-Performance Characteristics of a Multiple Cylinder Diesel Engine Fueled with Diesel-Jatropha Biodiesel Blend. Energy Conversion and Management, 94, 84-94. https://doi.org/10.1016/j.enconman.2015.01.047

[12] Canacki, M., Ozsezen, N.A., Arcaklioglu, E. and Erdil, A. (2009) Prediction of Per- 
formance and Exhaust Emissions of a Diesel Engine Fueled with Biodiesel Produced from Waste Frying Palm Oil. Expert Systems with Applications, 36, 9268-9280. https://doi.org/10.1016/j.eswa.2008.12.005

[13] Lesnik, L., Iljaz, J., Hribernik, A. and Kegl, B. (2014) Numerical and Experimental Study of Combustion, Performance and Emission Characteristics of a Heavy-Duty DI Diesel Engine Running on Diesel, Biodiesel and Their Blends. Energy Conversion and Management, 81, 534-546. https://doi.org/10.1016/j.enconman.2014.02.039

[14] Pinzi, S., Rounce, P., Herreras, J.M., Tsolakis, A. and Dorado, M.P. (2013) The Effect of Biodiesel Fatty Acid Composition on Combustion and Diesel Engine Exhaust emIssions. Fuel, 104, 170-182. https://doi.org/10.1016/j.fuel.2012.08.056

[15] Li, L., Wang, J.X., Wang, Z. and Xiao, J.H. (2015) Combustion and Emission Characteristics of Diesel Engine Fueled with Diesel/Biodiesel/Pentanol Fuel Blends. Fuel, 156, 211-218. https://doi.org/10.1016/j.fuel.2015.04.048

[16] Cheng, C.H., Cheung, C.S., Chan, T.L., Lee, S.C., Yao, C.D. and Tsang, K.S. (2008) Comparison of Emissions of a Direct Injection Diesel Engine Operating on Biodiesel with Emulsified and Fumigate Methanol. Fuel, 87, 1870-1879.

https://doi.org/10.1016/j.fuel.2008.01.002

[17] Fazal, M.A., Haseeb, A.S.M.A. and Masjuki, H.H. (2010) Comparative Corrosive Characteristics of Petroleum Diesel and Palm Biodiesel for Automotive Meterials. Fuel Processing Technology, 91, 1308-1315. https://doi.org/10.1016/j.fuproc.2010.04.016

[18] Hasimoglu, C., Ciniviz, M., Özsert, I., Içingür, Y., Parlak, A. and Salman, M.S. (2008) Performance Characteristics of a Low Heat Rejection Diesel Engine Operating with Biodiesel. Renewable Energy, 33, 1709-1715.

https://doi.org/10.1016/j.renene.2007.08.002

[19] Wang, X., Ge, Y.S., Yu, L.X. and Ferg, X.Y. (2013) Comparison of Combustion Characteristics and Brake Thermal Efficiency of a Heavy-Duty Diesel Fueled with Diesel and Biodiesel at High Altitude. Fuel, 107, 852-858.

https://doi.org/10.1016/j.fuel.2013.01.060

[20] Ghobadian, B., Rahimi, H., Nikbakht, A.M., Najafi, G. and Yusaf, T.F. (2009) Diesel Engine Performance and Exhaust Emission Analysis Using Waste Cooking Biodiesel Fuel with an Artificial Neural Network. Renewable Energy, 34, 976-982. https://doi.org/10.1016/j.renene.2008.08.008

[21] Arnand, K., Sharma, R.P. and Mehta, P.S. (2011) Experimental Investigations on Combustion, Performance and Emissions Characteristics of Neat Karanji Biodiesel and Its Methanol Blend in a Diesel Engine. Biomass and Bioenergy, 35, 533-541. https://doi.org/10.1016/j.biombioe.2010.10.005

[22] Moron-Villarreyes, J.A., Soldi, C., de Amorim, A.M., Pizzolatti, M.G., de Mendonca Jr., A.P. and D'Oca, M.G.M. (2007) Diesel/Biodiesel Proportion for By-Compression Ignition Engines. Fuel, 86, 1977-1982. https://doi.org/10.1016/j.fuel.2007.01.003

[23] Usta, N., Öztürk, E., Can, Ö., Conkur, E.S., Nas, S., Çon, A.H., Can, A.Ç. and Top$\mathrm{cu}$, M. (2005) Combustion of Biodiesel Fuel Produced from Hazelnut Soapstock/Waste Sunflower Oil Mixture in a Diesel Engine. Energy Conversion and Management, 46, 741-755. https://doi.org/10.1016/j.enconman.2004.05.001

[24] Yilmaz, N. and Morton, B. (2011) Effects of Preheating Vegetable Oils on Performance and Emission Characteristics of Two Diesels Engines. Biomass \& Bioenergy, 35, 2028-2033. https://doi.org/10.1016/j.biombioe.2011.01.052

[25] Geratebau, G. and Barsbüttel, G. (2000) Instruction Pour Experience CT151 Moteur 
Diesel 4 Temps Pour CT159. Manuel dinstruction, 17-18.

[26] https://www.total.fr/pro/produits-services/fioul-lourd/boite-a-outils/calculer-pci

[27] Daho, T., Sanogo, O., Jeanmart, H. and Kouldiati, J. (2008) Evaluation des performances et des émissions polluantes d'un moteur diesel à injection indirecte fonctionnant avec différentes huiles végétales et leurs mélanges au gas-oil. Journal de la Société Ouest-Africaine de Chimie, 26, 1-9.

[28] Valente, O.S., da Silva, M.J., Duarte Pasa, V.M., Belchior, C.R.P. and Sodré, J.R. (2010) Fuel Consumption and Emissions from a Diesel Power Generator Fuelled with Castor Oil and Soybean Biodiesel. Fuel, 89, 3637-3642.

https://doi.org/10.1016/j.fuel.2010.07.041 